\title{
Richard Murphy: Autobiography and the Connemara landscape
}

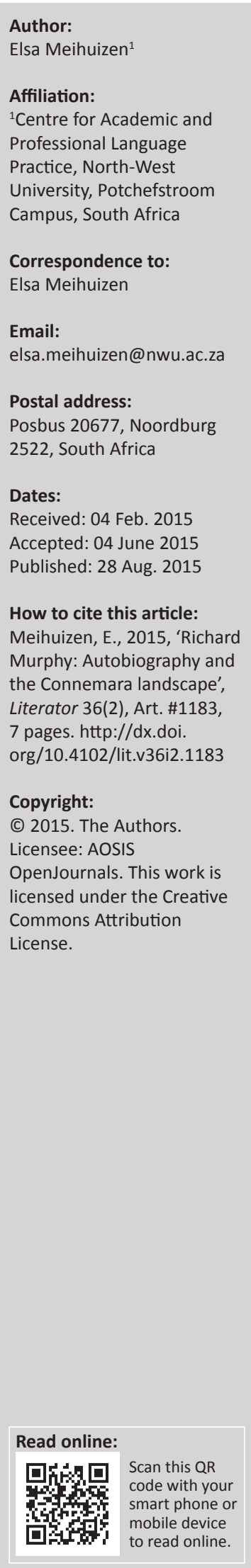

It could be argued that an important feature of Richard Murphy's work, and of his identity as a poet is the relationship between the creative self and a particular place, where 'place' should be understood as referring not just to physical qualities of the natural environment, but in a broader sense to denote an environment in which everything is interrelated and connected, and in which there is no sharp division between the natural and the human. The landscape providing inspiration for Murphy's poetic imagination is the landscapes and seascapes of Connemara in north-west Ireland. In 1959 he settled in this environment which was to be his base for the next 20 years and from this period and this location emanated the bulk of his poetic oeuvre. For Murphy committing to a life of writing poetry necessarily means being in the Connemara landscape. Returning to this environment in adulthood represents a quest for recovering childhood feelings, of belonging and love, as connected to particular places. Murphy's Connemara poems could be read as an account of this process of re-placement, as a type of autobiographical text in which the artist creates a 'double portrait': in writing about the landscape he also writes about himself, creating a place-portrait which is, at the same time, a self-portrait.

Richard Murphy: Outobiografie en die Connemara-landskap. 'n Noue verbintenis tussen die kreatiewe self en ' $n$ spesifieke plek kan gesien word as ' $n$ belangrike kenmerk van die werk van die Ierse digter Richard Murphy. 'Plek' binne hierdie verband beteken nie bloot die fisiese kenmerke van die natuurlike omgewing nie, maar dui in 'n breër sin die omgewing aan waarin alles onderling verbind is en waarin daar geen skerp verdeling bestaan tussen natuur en mens nie. Die landskap van Murphy se poëtiese inspirasie is die gebied bekend as Connemara in die noordweste van Ierland. Murphy vestig hom in 1959 in hierdie omgewing waar hy vir die volgende 20 jaar sou bly en waar die grootste gedeelte van sy poëtiese oeuvre tot stand kom. Toewyding aan 'n lewe as digter is vir Murphy onlosmaaklik verbonde aan die Connemara-landskap. Hy keer as volwassene terug na hierdie omgewing in 'n poging om die geborgenheid en liefde terug te vind wat hy in sy kinderdae ervaar het en wat vir hom gekoppel is aan spesifieke milieus. Murphy se Connemara-gedigte kan gelees word as die verwoording van hierdie proses van hervestiging; as 'n tipe outobiografiese teks waarin die digter 'n 'dubbelportret' tot stand bring: wanneer hy oor die landskap skryf, skryf hy terselfdertyd oor homself; skep hy 'n portret van 'n plek en ook van homself.

\section{Introduction}

Richard Murphy emerged as an important figure in Irish literature in the course of the 1960s amongst other poets such as John Montague, Derek Mahon, Thomas Kinsella and Seamus Heaney ${ }^{1}$. The bulk of his poetry was published in five volumes, brought together in a series of collected works. ${ }^{2}$

An important feature of Murphy's work and of his identity as a poet is the relationship between the creative self and a particular place. For Murphy the environment providing inspiration for his poetic imagination is the landscapes and seascapes of Connemara. Committing to a life of

\footnotetext{
1.The period between 1960 and 1990 is often described as the 'Irish Renaissance' in terms of economic development and an accompanying revival of the creative arts. Kiberd (1996:565-613) provides a useful discussion of the nature and the major exponents
of this period in Irish literature. For the importance of Murphy as poet see Harmon (1977), Heaney (1977), Haffenden (1980), Sendry of this period in Irish literature. For the importance of Murphy as poet see Harmon (1977), Heaney (1977), Haffenden (1980), Sendry
(1985), O'Driscoll \& Murphy (1988), Denman (1989), Swann (1990), Drabble (1995), Welsh (1996), Leddy (2001), Mahony (2002), Sendry (2002), Skloot (2002).

2.The major volumes are: Sailing to an island (1963), The battle of Aughrim and the god who eats corn (1968), High island (1974), The price of stone (1985), and The mirror wall (1989). Murphy's poetry was also published in the United States, sometimes at the same time as in the United Kingdom, but at times at different dates and with slightly different combinations of poems. Collections and selected volumes are: Selected Poems (1979), New selected poems (1989), Collected poems: 1952-2000 (2001), and The pleasure ground: Poems 1952-2012 (2013).
} 
writing poetry for Murphy necessarily means being in the Connemara landscape and, furthermore, returning here as an adult and settling down to write poetry and earn a living represent a quest for recovering childhood feelings of belonging and love connected to specific environments. Murphy's Connemara poems could be read as an account of this process of re-placement, as a type of autobiographical text in which portrayal of the landscape also amounts to portrayal of self.

\section{Being in Connemara and writing poetry}

Connemara is the broad peninsula in north-west Ireland between Killary Harbour and Kilkieran Bay in County Galway, bounded on the west, south and north by the Atlantic and stretching eastwards to Loch Corrib. The coast of Connemara consists of a number of smaller peninsulas and is lined by numerous islands. Of these Inishbofin is the largest, whilst others include Omey, Inishark, High Island, Friar Island and Mainis.

The connection for Murphy between physically being in Connemara and writing poetry is linked to periods of happiness experienced here during childhood. He writes about this in his memoir, The kick, ${ }^{3}$ and in more detail in an earlier autobiographical essay entitled 'The pleasure ground'. ${ }^{4}$ This connection has received critical attention elsewhere ${ }^{5}$ and for the purposes of the present discussion it would suffice to restate the essentials. The pleasure ground was a walled garden at Murphy's grandparent's home, Milford, situated near the eastern border of county Mayo, and was in the family's possession since the 18th century and the Cromwellian settlement in Ireland of loyal Protestants. The original pleasure ground has fallen into decay and was restored by Murphy's mother after a part of the ancestral house was converted into living quarters for her and the children in 1935, whilst Murphy's father worked overseas. The enduring influence of the pleasure ground period on Murphy's life is linked in particular to a period of time when he was 12 years old, and which, because of the war, the children spent at Milford. He recalls this as the happiest time of his life, but tells us that it did not last, because:

[s]ome of us went to boarding-schools in England, other settled abroad ... [t]he garden fell back into decay ... [t]he spirit I was looking for in the yew-berry, the fig and the beech-tree had withdrawn - that spirit which had once made poetry and music and painting, even mathematics, an effortless delight. (Murphy 1964:65-66)

During the pleasure ground period the Murphys visited the north-west coast of Connemara with their grandmother, Lucy Ormsby (Thompson), who grew up at Salruck on Little Killary Bay. For Murphy the people of this region were 'truly

\footnotetext{
3.See Murphy (2003).

4.See Murphy (1964). An adapted version of 'The pleasure ground' is included in Murphy (2013). Both versions are taken into account here.

5.See Heaney (1977) and Meihuizen (2006).
}

Irish', 'seemed sharper, freer ... stones, salmon-falls, rainclouds and drownings had entered and shaped their minds, loaded with ancestral bias', and he tells us that 'that's what my brother and I wanted to be' (Murphy 1964:65). Also, as a younger child, Murphy spent some time in this area with his family, and of this experience he writes:

My love of the north-west corner of Connemara goes back to the summer of my eighth birthday at Rosleagh, a big, ivy-clad house standing high among trees with a view of the Diamond mountains and the rotting hulks of trawlers at the quay of Letterfrack./ ... It was the last time and place in which all five of us children were to live at home with both parents and Nanny. (Murphy 2003:39)

When the spirit of the pleasure ground was lost, Murphy tells us: '... I went back to that other, older pleasure ground in the treeless hills, on the sea's edge, and rediscovered Connemara ...' (Murphy 1964:66).

The rediscovery of Connemara referred to here is the summer of 1946 during which Murphy, whilst studying at Oxford, went back to Milford, learnt to drive, and rented a primitive cottage on the Camus River near Screebe. Here he devoted himself to writing a tragedy in verse about a medieval Irish legend. Of this experience he writes in his memoir:

By the Camus River, with the smell of peat smoke, the sound of rain dashing on tiny windowpanes, and the lyrical harsh voices of my poor landlord's family of ten who spoke almost nothing but Irish, my verse began to flow./ ... Here I became convinced with religious intensity that the poetry I wanted to write would be written in Connemara. (Murphy 2003:97)

Murphy's conviction that he had to be in Connemara to write poetry remained despite being able to spend only short periods of time there for the next 13 years, and during this time he was mostly unsuccessful in getting work accepted for publication. In 1959, after his marriage failed, he returned to the Connemara coast which was to be his base for the next 20 years. From this period and this location emanated the bulk of Murphy's poetic oeuvre, published in the volumes Sailing to an island (1963), The battle of Aughrim and the god who eats corn (1968), High Island (1974), and The price of stone (1985).

\section{The Connemara landscape The concept 'landscape'}

For Murphy, returning to Connemara as a young man represents a deliberate choice between two environments (that of Oxford versus the 'truly Irish') and two vocations (criticism and scholarship versus writing poetry). His commitment to a life of writing poetry necessarily means settling in the Connemara landscape in a quest to replace the lost Anglo-Irish pleasure ground where as a child he experienced feelings of belonging and love. Murphy's Connemara poems could, therefore, be read as account of this process of re-placement, as a type of autobiographical text in which the portrayal of a new landscape reflects the portrayal of the self encountering this landscape. 
The concept 'landscape' as used in this context should be understood as referring not just to physical qualities of the natural environment but, in a broader sense, also denote an environment in which everything is interrelated and connected, and in which there is no sharp division between the natural and the human, between self and place. This understanding coincides with the critical employment of 'landscape' in a body of writing which in a broader sense could be described as eco-criticism or nature writing, but in which the specific concern is self-discovery and selftransformation through interaction with a particular milieu. ${ }^{6}$ Evernden (1978), for instance, proposes that, beginning in childhood, humans develop a sort of territoriality, a special relatedness to their particular place in the natural world. For him a discussion of the relationship of man and environment necessarily entails a consideration of the relation of self to setting, and he insists that there is no such thing as an individual, but only an individual-in-context, who '... sees a landscape not only as a collection of physical forms, but as the evidence of what has occurred there' (Evernden 1978:19). McDowell (1996:387-388) motivates his preference for the term 'landscape writing' as opposed to 'nature writing' by pointing out that the latter could be seen as ignoring humans and dealing only with the wild, with what is 'out there', whilst 'landscape' is all around us and suggests inevitable interaction and mutual influencing of humans and the nonhuman world.

Implied in this understanding of 'landscape', as inevitably dealing with interrelation and connection, is the recognition that the establishment of self is impossible without the context of place and, inversely, that landscape writing is necessarily autobiographical. Brooke (2000:252-253) observes that it is the unstated aim of all nature writing to 'write about the natural world and about oneself simultaneously, to look mutually outward and inward.' She suggests that 'we both produce and are produced by our encounters with the natural world' and points to 'the possibility of being simultaneously egoand ecocentric, individuated and integrated, and - once and for all - both human and "natural"'.

An interesting and particularly helpful way of thinking about texts, in which there is a concurrence of writing about the natural world and the self, is explored by Perreten (2003) in an article entitled 'Eco-autobiography: portrait of place/ self-portrait'. He provides an exposition of the appositional relationships between the terms included in the title with reference to earlier critical works, such as Beaujour (1991) and Wallen (1995), in which autobiography is seen as literary self-portrait, and to Evernden (1978) who likens landscape writing to landscape painting in the sense that in both art forms the artist attempts to capture personal knowledge of the essential qualities of his or her subject. The term 'ecoautobiography' is then employed in characterising a type of text comprising 'a "double portrait": an artist's self portrait in the context of a personal landscape or "place portrait"' (Perreten 2003:5).

\section{Involvement versus detachment}

An important characteristic of Murphy's poetry, pertinent to a discussion of the autobiographical element of his portrayal of the Connemara landscape, is a tension between personal involvement and detachment. In critiques of his work this issue often receives attention, albeit expressed in different terms and judged both as weakness and strength. ${ }^{7}$

An example of this concern is to be found in an early review of Murphy's work in which the poems included in Sailing to an island are judged as 'not good'. The critic sees in the writing 'too much detail' and the poet is deemed to be 'too close to what he describes, too engrossed in it and not able to make the external painting a reflection of his internal state' (Reynolds 1964:60-61). In a critique of a wider range of Murphy's poetic works Harmon (1977) expresses his appreciation for the narrative quality, clarity, objectivity, and detailed particulars of Murphy's poetry. The writing is described as 'faithful, almost documentary', an 'accurate record of things done and said' but, at the same time, this record is deemed to be related to and evaluated from Murphy's personal point of view 'relative to their meaning for one mind' (Harmon 1977:8). Seamus Heaney (1977), whilst making a more positive assessment of Murphy's work than Reynolds, is in agreement with her characterisation of it as an external painting rather than reflecting an internal state. Heaney compares Murphy to George MacKay Brown in pointing out similarities in subject matter and writing style, and expresses the opinion that both poets tend to keep themselves out of the poem, to be present as observers, anonymous voices, bearers of tales, shapers of material rather than explorers of the self. An important difference for Heaney between the two poets, is that Brown deeply identifies with the older, timeless archetypes of his artistic world whilst the characters, incidents and natural phenomena in the world of Murphy's poetry 'are observed not with votive attachment but with precise detachment' (Heaney 1977:18).

\section{Portrayal of the Connemara landscape}

Murphy's Connemara poems concern the sea, seamanship, boats, natural phenomena, people, myths and legends, the traditional way of life of the fisherman, and more contemporary social concerns. In this section the portrayal of the Connemara landscape in these poems is discussed, keeping in mind both the tension between attachment and detachment perceived in Murphy's poetry, as discussed above, as well as the notion of 'eco-autobiography' or 'double portrait' as employed by Perreten (2003).

In poems involving the people of Connemara Murphy writes about the traditional inhabitants such as seasoned

7.For critics expressing views in this regard see for instance Reynolds (1964), Harmon (1977), Heaney (1977), Swann (1990), Mahony (2002), Skloot (2002), and Sendry (2002). 
fishermen and novices in this trade, boat builders, farmers, tinkers, landlords, servants and saints, as well as visitors as famous as Ludwig Wittgenstein or Theodore Roethke. These human subjects are situated in the natural landscapes and seascapes and portrayed in images taken from this world. So, for instance, in the last stanza of 'Morning call' two teenage tinker girls (who turned up at Murphy's home early one morning, asking him to provide an alibi to protect them from expected trouble at home after spending a wild night in the trawlers on the fish docks) are described as:

Lovely as seals wet from fishing, hauled out on a rock

To dry their dark brown fur glinting with scales of salmon

When the spring tide ebbs. This is their everlasting day

Of being young. They bring to my room the sea's iodine odour

On a breeze of voices ruffling my calm as they comb their long

Hair tangled as weed in a rock pool beginning to settle clear.

Give me the sea-breath from your mouths to breathe a while! ${ }^{8}$

In imagery taken from the sea the poem provides a vivid picture of the tinker girls' youth, beauty and liveliness, whilst hinting at habits of reckless pleasure and a violent domestic situation against which they are seeking Murphy's protection. The real significance of the encounter for the author lies in the realisation of the contrasts between his own life and that of the girls. They disrupt his peaceful, solitary life waking him 'at sunrise from a single bed'. Their entrance is equated to 'a flood that crosses the threshold', their voices to 'a breeze ... ruffling my calm'. But they also bring with them renewal ('little blue waves ... freshening my brackish pools') and a reminder of what it is like to live as if life is an 'everlasting day of being young'. The plea uttered by the author in the last line of the poem reflects the understanding that he actually is the one in need of being saved, resuscitated by their natural vitality suggested here by the image 'seabreath'. In the love poem 'A nest in the wall' the speaker also borrows images from the surrounding landscape in addressing the beloved. The lover is likened to a woodpigeon and a wren, with hair 'smokey as peat' burning 'like a tinker's fire in a mossy ditch', a mouth promising 'a tincture of mountain ash,/ A red infusion of summer going to seed', and the emotions flowing from their encounter are equalled to processes of nature, such as in:

Ivy-clumps loosen the stonework of my heart.

Come like a wood-pigeon gliding there to roost!

I float a moment on a gust sighing for ever

Gently over your face where two swans swim.

Let me kiss your eyes in the slate-blue calm

Before their Connemara clouds return.

In both poems the suggestive power of the images taken from the landscape provides a mechanism of distancing, making it easier to speak about the intimate and emotional. For Murphy's own motivation of the use of this type of manoeuvre, comments made in two interviews are instructive. The first is an interview with John Haffenden published in London Magazine in 1980. Haffenden observes

8.Quotations from poems are from Murphy (2013). Minor revisions were made to some poems for inclusion in this volume. that Murphy seems to set himself extremely difficult metrical and prosodic exercises in writing his poetry, and infers from this that Murphy undertakes certain poems in a spirit of detachment from the subject. In Murphy's reaction, which amounts to the opposite being true, he refers to the intricate formal elements of poems written about the death of a loved one and says that when he started to write the first of these poems 'it came out in very strict rhymes, effortlessly, which is unusual for me, since I find rhyming rather difficult'. He concludes his answer by saying that 'form wasn't imposed like a uniform upon a recruit' but 'came from the depths ... to distance this terrible subject matter, to cool it sufficiently so that it becomes bearable and not just shocking or disgusting' (Haffenden 1980:13). As part of another interview with Dennis O'Driscoll, Murphy explains his use of perspective in 'The price of stone', the sequence of fifty sonnets published in 1985 in which buildings of personal relevance to the poet are personified and speak in the first person. Murphy says:

After uprooting myself painfully from Connemara, I felt I never wanted to become so deeply attached to a place again ... So, in The Price of Stone I converted many of my former homes into sonnets expressing their spirit ... (this) identification of some part of myself with the building ... was liberating. Having discovered this, I was able to speak more revealingly, without confessional embarrassment, from oblique perspectives. (O’Driscoll \& Murphy 1988:14-15)

Although in the quoted reactions from these interviews Murphy is referring specifically to rhyme and perspective, this applies in a broader sense to the function of formal aspects of his poetry in general, namely as a vehicle for detachment which, paradoxically, enables him to find words for what would otherwise be unbearably personal, 'shocking or disgusting'. The two poems discussed above represent examples of the use of images from the landscape for this function. It is as if Murphy identifies himself with the landscape to the same extent as with the structures in the sonnet sequence, enabling him to speak more revealingly about himself through the images taken from the natural environment without 'confessional embarrassment'.

The essentially autobiographical nature of Murphy's writing about the Connemara landscape is evident in the narrative poems where, although the subject appears to be something external, the stories are often rooted in personal experience and are essentially vehicles employed for writing about encounters between self and landscape. A prime example is the title poem of Murphy's first volume Sailing to an island, a first person narrative of a boat journey which at first seems to be about seamanship, the beautiful but treacherous nature of the sea, and the way of life of the islanders coloured by history, legend and tradition. In essence, however, the journey is experienced as a test, a failed rite-of-passage by the ' $I$ ' of the poem. In entering the world of the island dwellers the focus is on a painful self-awareness of being an outsider and being scrutinized, judged and dismissed by the islanders. This world, however, also offers the possibility of a place of rest and settling down, as expressed in the last 
line of the poem in the statement: 'Here is a bed.' No further explanation for this realisation is offered in this poem, but in his memoir Murphy writes:

As we sailed through a short narrow channel to a little inner harbour watched by a group of fishermen on the quay, I felt we were arriving among descendants of people long ago marooned on an island where they lived in the fear of God and believed in miracles, travelled on foot or horseback, and lit their houses with oil lamps and candles, as we had done at Milford during the war. (Murphy 2003:141)

'Sailing to an island' can, thus, be read as the prelude to the story of Murphy's settlement on the Connemara coast in replacement of the pleasure ground of his childhood.

In 'The last Galway Hooker' Pat Cloherty, the boatwright, storyteller, and balladeer from Inishbofin is introduced by placing him within the natural and historical environment:

Where the Corrib river chops through the Claddagh

To sink in the tide-race its rattling chain

The boatwright's hammer chipped across the water

Ribbing this hooker, while a reckless gun

Shook the limestone quay-wall, after the Treaty

Had brought civil war to this fisherman's town.

Although the objective third person perspective is adopted in the first two sections of the poem recounting the history of the boat, the third section starts with: 'We met here last summer, nineteen fifty-nine,/ ... And we drank looking out on the island quay,/ ...With a farewell song he sold me the Ave Maria.' The rest of the poem is not about the last Galway hooker as such, but concerns the personal history of the ' $\mathrm{I}$ ' who, we are told '... chose to renew her, to rebuild, to prolong/ For a while the spliced yards of yesterday' in order to secure for himself a place, a future in this world of oceans, boats and boatmen, as becomes clear in the wish expressed in the closing line: 'May I handle her well down tomorrow's sea-road.' The story about the renewal of the Ave Maria is also the story of Murphy's self-renewal reflected in the concluding remark of his account of the restoration of the hooker in his memoir: 'For me ... restoring the old hooker was the start of a new life' (Murphy 2003:189).

Murphy's Connemara poems also deal with purely natural phenomena such as the islands, plants, birds, and animals of the region but at the same time, although this is not always immediately obvious, with emotions, experiences or processes concerning the life of the author. A number of poems can be singled out as examples of how this fusion between the natural and the autobiographical is achieved.

'Sea holly' starts with a detailed description, providing information closely resembling scientific botanical style, about the plant's habitat, growth pattern, and physical appearance. The presence of the observing narrator becomes obvious only towards the end of the poem. One of the facts provided about the plant is that it spends most of the year underground and only crops up briefly in summer, followed by the question:
'How can it raise/ Enough energy to rise above the sand/ and open its eyes?' For the observer the personification, of the plant as having 'eyes' based on the physical similarities in the appearance of the flowers and human eyes, seems to function as the trigger for the comparison between the growth pattern of the plant and human behaviour following directly thereafter in the closing couplet with: 'Like yours, the colour of hurt, they want to hide/ Until in a blaze of blue spikes they explode'. Once it is clear that the poem is not just about the sea holly but also about human relations, about behaviour and emotions in which the observer plays a role, the deliberate choice of words is evident, that can be interpreted as denoting human actions and qualities, in descriptions like 'wearing stiff armour embossed with', 'haggard' and 'stupefying torpor' comes into sharper focus.

Whilst in 'Sea holly' the retrospective infusion of what seems at first a purely factual description with the personal is achieved within a single poem, in other instances this process is at work in two or more poems. As example of this we can consider two poems on High Island, one is of the small islands off the Connemara coast which Murphy owned for a number of years, and where he spent periods of time, mostly on his own. ' 'High Island' gives a description mainly of purely natural elements with a brief reference to the ruins of a mill and a chapel. The stark darkness of the island is contrasted with softer elements of light and colour. In 'Ardilaun' the Anglicized form of the Irish name for the island (Ard Oilean) is used. Here the natural environment is also described in detail with an underlying tension between dark and light. The darkness is, however, lifted, replaced by light, and it becomes evident towards the end of the poem that this process in nature mirrors the shedding of an emotional burden of the speaker, the ' $\mathrm{I}$ ' of the last stanza. Throughout the poem descriptions of changes in the natural environment and inanimate structures (light, angelica, schist, ferns, daisies, clouds, beehive cells, graves, crosses and a chapel) are phrased in such a way that they can be read also as actions and processes of a human nature '(lifting up ... parasols', 'to poke new heads through cracks', 'gloom will lift'), and in some cases descriptions make proper sense only when it is understood as such (compare, for instance: 'calculated solitude', 'to celebrate', 'penitential crosses'). The similarity of title and detail in the two poems functions as a key for reading them together, and in doing so the personal human experience present in the one also resonates in the other.

This tension also holds, in a slightly different way, for the poems 'The afterlife' and 'Circles'. In 'The afterlife' the speaker, who seems to be watching birds, notices through the lenses of his binoculars swans taking off and a heron gliding down 'to poise on a rock/ In a clump of reeds and waterlilies'. The scene watched is situated 'below my hexagon'10 which establishes Murphy himself as the focal

9.For an account of the poet's connection to High Island and its significance for him see Murphy (2003:275-278, 280-285, 288-293).

10.See Murphy (2003:308-310). 
character, looking out from the home he had built on Omey Island and which is the subject of 'Hexagon' in the sonnet sequence 'The price of stone'. The presence and movements of the heron command his attention for most of the rest of the poem, particularly because he perceives the bird to look back not just at him, but at 'All the eyes in the country/ That are looking at him' using 'the power of his vision'. The poem is concluded by the question 'Could this be the bird/ That soared from a rock in lake water/ As our friend's ashes broke out of your pot?' which, in this context, remains cryptic. The personal significance of the heron for the observer, and the personal history which prompts the question become clear when the poem is read together with its counterpart 'Circles'. 'Our friend', 'he', 'Tony' of whom the two poems speak is Tony White, who Murphy met on his arrival in Inishbofin, as described in the poem 'Double negative', and who became a soul mate, but died unexpectedly in 1976. White is the subject of a number of other poems such as 'Tony White', 'Tony White at Inishbofin', 'Bookcase for the Oxford English Dictionary', and 'Tony White's cottage'. The poet's detailed attention to the heron, his sustained description of its movements, and his endowment of the bird with a special vision in 'The afterlife' is, thus, explained by the circumstances of this friendship and the loss of it.

The typical pattern in which the coexistence of the portrayal of landscape and self becomes apparent when poems are read together also exists for groups larger than two. An example of this is the following series: 'Little Hunger', 'Walking on Sunday', 'Omey Island', 'Cottage for sale', 'Stone mania', 'Granite globe', 'Hexagon' and 'New Forge'. Read on their own some of these poems seem to describe places, events or structures, but read together they tell the story of Murphy's ambivalence about his sustained involvement in building, especially in granite from the Connemara region. Building becomes a metaphor for the creative act, preservation, restoration, and renewal, but also for greed, destruction, and obsession. Another interesting group consists of poems which apparently concern birds, namely: 'Corncrake', 'Song for a corncrake', 'Coppersmith', 'Stormpetrel', and 'Nocturne'. Whilst these poems contain the typically detailed descriptions of the subject and the natural setting, the account is phrased in terms which could be read as denoting human actions, qualities and processes. Particular concerns in these poems are the quality and the communicative value of the bird's song. For instance, 'Corncrake' starts with:

Petty boss of a ditch

Why so much energy and such a boring song?

Surely your mate must be tired of hearing

How little you have to say

And how often you repeat yourself'.

In 'Song for a corncrake' the first line of each of the three stanzas is a question put to the bird: 'Why weave rhetoric on your voice's loom', 'Why draft an epic on a myth of doom' and 'Why go on chiselling mottoes for a tomb'. The cryptic nature and incoherence of the cries of petrels in 'Nocturne' is suggested as follows in the last two stanzas in broken lines such as: 'I'm here here/ This burrow this wall this hole' and
'There there there/ It's all over over over'. It is evident that the flawed communication of the birds echo the poet's anxieties about his own 'songs'. The function of identifying with the birds in these poems is similar to the author's identification with buildings in 'The price of stone' as illustrated in quoting Murphy's comments in this regard above.

\section{Conclusion}

It has been pointed out earlier in this essay that a dichotomy between personal involvement and detachment is often perceived in Murphy's poetry. From the discussion of examples of the Connemara poems, it became evident that detachment does not equal impersonality, but that in employing manoeuvres of detachment the poet finds greater freedom to write about his own life. I would like, in conclusion, to return to this issue with reference to a number of critical analyses relevant to a consideration of the Connemara poems as 'eco-autobiography' as defined for the purposes of this discussion.

The quality of detachment which critics identify in Murphy's poetry is often seen as a shortcoming as is evident, for instance, in the critiques offered by Reynolds (1964) and Heaney (1977). I think it is possible to make a different assessment. As point of departure I would like to single out two passages from Heaney's article. Heaney (1977) says that when Murphy writes about the Connemara environment he is:

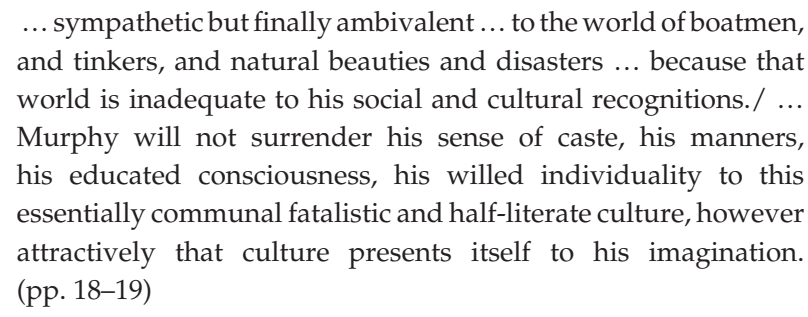

In the second passage this judgement is repeated although formulated slightly differently and in agreement with a reading offered elsewhere by Edna Longley. With reference to the poem 'Rapparees', which forms part of 'The battle of Aughrim', Heaney writes that, in spite of Murphy's intention in this cycle of poems to exorcise ancestry, his language retains its ancestral bias in the idiom used to describe essentially Irish phenomena:

$\ldots$ at a moment when the tutelar presences of the Irish ground
are being summoned, they are subtly debilitated by the idiom
in which they surface. It is not that Murphy wishes to rob them
of their proper force; it is more that his language retains its
ancestral bias in spite of his intention to exorcise ancestry as a
determining limit of vision.

Mention of the poet's intention brings us to the critical crux. I agree with Edna Longley that 'something programmatic in its design and designs ... stands in the way of total subjection of the offered experience' and I am tempted to formulate my sense of what is missing, perhaps too glibly, in words from Robert Frost's 'The Gift Outright', also a poem about the relationship of self to historical and geographical continuities:

Something we were witholding made us weak 
Until we found out that it was ourselves

We were witholding from our land of living,

And forthwith found salvation in surrender.

(Heaney 1977:26-27)

That Murphy is an outsider to the world of boatmen, tinkers, and natural beauties and disasters is of course true. Those acquainted with his poetry and his autobiographical prose writing also know that the poet remains intensely aware of this status. However, considering Murphy's oeuvre, it would not be true to say that his 'program' includes surrendering or exorcising the heritage which formed his manners, educated consciousness, individuality, or language. Indeed, writing poetry which in its design and execution remains aware of and true to a self divided, between two worlds, constitutes one of the true strengths of Murphy's poetry. Murphy expresses this awareness, for instance, as follows in reference to his approach in writing 'The battle of Aughrim':

The poem grew slowly, because organically, from bits and pieces of my life and reading in Ireland between 1962 and 1967, not as a set-piece epic about a battle in the seventeenth century. My underlying wish was to unite my divided self, as a renegade from a family of Protestant imperialists, in our divided country in a sequence faithful to the disunity of both. (Murphy 2003:220)

In commenting on the quality of the poems, included in the volume High Island, Swann (1990:38-39) characterises them as descriptions which succeed in 'knitting together a world of things seen, things felt, things signified' and in presenting 'emotion which seeks union with the unresponsive world'. He sees in Murphy's poetry moments of consummation which have a 'rare quality, for they depict the movement of the emotions with a nakedness and an accuracy which is the counterpart to the exactitude with which Murphy otherwise chronicles his world.' The exactitude in which 'things seen' are portrayed signals for the critic 'an act of homage to something that can never be entirely assimilated' (Swann 1990:42).

Murphy's distanced, restrained portrayal of the world of boatmen, tinkers, natural beauties and disasters evident in the exactitude in which he chronicles this world, is then a deliberate poetic stance. This stance signifies the acceptance of an identity which he can never fully assume. And this acceptance is necessary if Murphy is to succeed in discovering in writing poetry both a new landscape and a new self in the pleasure ground on the edge of the sea.

\section{Acknowledgements Competing interests}

The author declares that she has no financial or personal relationships which may have inappropriately influenced her in writing this article.

\section{References}

Beaujour, M., 1991, Poetics of the literary self-portrait, transl. Y. Milos, New York University Press, New York.

Bergman, C., 1996, “"The curious peach": Nature and the language of desire', in C.G. Herndl \& S.C. Brown (eds.), Green culture: Environmental rhetoric in contemporary America, pp. 281-303, University of Wisconsin, Madison.

Brooke, L., 2000, 'Nature writing as Refuge: Autobiography in the natural world', in J. Tallmadge \& H. Harrington (eds.), Reading under the sign of nature: New essays in ecocriticism, pp. 251-279, The University of Utah Press, Salt Lake City.

Denman, P., 1989, 'New selected poems by Richard Murphy: The mirror wall by Richard Murphy', The Poetry Ireland Review 26, 55-59.

Drabble, M. (ed.), 1995, The Oxford companion to English literature, Oxford University Press, Oxford.

Evernden, N., 1978, 'Beyond ecology: Self, place and the pathetic fallacy', North American Review 263(4), 16-20.

Goodbody, A., 2011, 'Sense of place and Lieu de Mémoire: A cultural memory approach to environmental texts', in A. Goodbody \& K. Rigby (eds.), Ecocritical approaches: New European approaches, pp. 55-67, University of Virginia Press, Charlottesville/London.

Haffenden, J., 1980, 'Richard Murphy: A conversation in Connemara', London Magazine 19(12), 9-23.

Harmon, M., 1977, 'The poet and his background', Irish University Review 7(1), 7-9.

Heaney, S., 1977, 'The poetry of Richard Murphy', Irish University Review 7(1), 18-30.

Kiberd, D., 1996, Inventing Ireland: The literature of the modern nation, Harvard University Press, Harvard.

Leddy, M., 2001, 'Collected poems, 1952-2000 by Richard Murphy', World Literature Today 79(3/4), 155-156.

Mahony, C.H., 2002, 'Collected poems 1952-2000 by Richard Murphy', The Canadian Journal of Irish Studies 27(2)/28(1), 149-150.

McDowell, M.J., 1996, 'The Bakhtinian road to ecological insight', in C. Glotfelty \& H. From (eds.), The ecocriticism reader, pp. 371-391, The University of Georgia Press, Athens and London.

Meihuizen, E., 2006, 'Richard Murphy: A life in writing', Literator 27(3), 157-174. $\mathrm{http} / / / \mathrm{dx}$.doi.org/10.4102/lit.v27i3.205

Murphy, R., 1963, Sailing to an island, Faber and Faber, London.

Murphy, R., 1964, 'The pleasure ground', in H. Read (ed.), Writers on themselves, pp. 62-66, British Broadcasting Corporation, London.

Murphy, R., 1968, The battle of Aughrim and the god who eats corn, Faber and Faber, London.

Murphy, R., 1974, High island, Faber and Faber, London.

Murphy, R., 1979, Selected poems, Faber and Faber, London.

Murphy, R., 1985, The price of stone, Faber and Faber, London.

Murphy, R., 1989, New selected poems, Faber and Faber, London.

Murphy, R., 2001, Collected poems 1952-2000, The Gallery Press, Dublin.

Murphy, R. [2002] 2003, The kick: A life among writers, Granta Books, London.

Murphy, R., 2013, The pleasure ground: Poems 1952-2012, Bloodaxe Books, Tarset, (Northumberland UK).

O'Driscoll, D. \& Murphy, R., 1988, 'Richard Murphy at sixty', The Poetry Ireland Review $21,14-18$.

Perreten, P.F., 2003, 'Eco-autobiography: Portrait of place/self-portrait', Auto/ Biography Studies 18(1), 1-22.

Reynolds, L., 1964, 'Sailing to an island by Richard Murphy', Irish University Review 3(4), 60-61.

Sendry, J., 1985, 'The poet as builder: Richard Murphy's "The price of stone"', Irish University Review 15(1), 38-49.

Sendry, J., 2002, 'No room for wasted effort: Collected poems by Richard Murphy', The Poetry Ireland Review 72, 50-52.

Skloot, F., 2002, 'Collected poems 1952-2002 by Richard Murphy', Harvard Review 23, 171-173.

Swann, J., 1990, 'The historian, the critic and the poet: A reading of Richard Murphy's poetry and some questions of theory', The Canadian Journal of Irish Studies 16(1), 33-47. http://dx.doi.org/10.2307/25512807

Wallen, J., 1995, 'Between text and image: The literary portrait', Auto/Biography Studies 10, 50-56

Welsh, R. (ed.), 1996, The Oxford companion to Irish literature, Oxford University Press, Oxford. 